\title{
РЕАЛЬНЫЙ ФЕДЕРАЛИЗМ КАК ФАКТОР СТАБИЛИЗАЦИИ РОССИЙСКОГО ОБЩЕСТВА
}

\section{Р.Г. В аги иов*}

За 50 лет Всеобщая декларация прав человека оказала существенное влияние не только на разработку и принятие международных стандартов в области прав человека, но и на достижение эффективности их осуществления в самих государствах, поскольку соблюдение прав и основных свобод человека может быть гарантировано только самим государством.

От того, на каком уровне находится состояние прав человека в государстве, ках защищаются права человека, зависят становление и развитие демократических процессов в обществе, проявление благосостояния его граждан, развитие и процветание государства.

В конце XX века заметно возросло значение прав человека и прав народов, их цивилизованного и универсального соблюдения. А один из реальных путей к тому - строительство новых и модернизация существующих федеративных отношений. Именно на это столетие приходятся резкое увеличение числа федеративных государств и договоров, все более широкое распространение идей и принципов федерализма. В настоящее время одна десятая стран, представленных в $\mathrm{OOH}$, имеет федеративную структуру, а проживает в них более трети населения мира. По другим данным, в пределах государств, которые являются формально федеративными, проживает почти $40 \%$ населения земли и еще одна треть населяет государства, которые в той или иной мере исповедуют федеративные принципы, оставаясь формально унитарными.

Проблема федерализма имеет особое значение на нынешнем этапе формирования российской государственности. Именно сейчас закладываются принципиальные основы и механизм функционирования федеральных отношений в нашей многонациональной стране со сложной историей и судьбой.

Вспомним Ф. Бэкона: "Выбрать время - значит сберечь время, а что сделано несвоевременно - сделано понапрасну".

15 февраля 1994 г. был подписан Договор между Республикой Татарстан и Российской Федерацией о взаимном делегировании полномочий. Он стал первым договором в истории России, положившим начало формированию принципиально новых отношений Центра с регионами.

* Кандидат юридических наук, Председатель Комиссии по вопросам законодательства, законности, правопорядка и депутатской этики Госсовета Республики Татарстан. 
Смысл его состоял в закреплении мирного, устраивающего обе стороны пути разрешения сложной политической и юридической коллизии. Он не только определил новую структуру отношений с Татарстаном, но и выбрал механизм реализации прав республики, чего не могли добиться регионы в рамках федерального договора.

Среди российских политиков есть немало тех, кто видит в договорной практике политическую конъюнктуру. Они предлагают покончить с "игрой в договоры и в парад суверенитетов" и перейти $\mathrm{K}$ "исконному", "традиционному" централизованному управлению. Сегодня стало очевидным, что попытки решать проблемы в отношениях Центра с субъектами силовым способом - тупиковый путь, чреватый для страны не только кризисами, наподобие чеченского, но и самораспадом государства.

Сверхцентрализация была одной из наиболее характерных черт российской государственности, от которой многим нелегко отказаться в силу политических традиций. Однако сегодня трудно представить возможность возврата к прежним устоям. Россия встала на путь демократии, федерализма и экономических реформ. Чтобы повернуть страну вспять, нужна новая революция, а для этого у российского народа сил уже не хватит.

Государственное переустройство России - явление эпохальное каик для страны, так и для всего мира, ибо речь идет об отказе от имперского наследия, тоталитаризма и великодержавности. На этом направлении договорный процесс становится магистральным путем реформирования старых структур. Неэффективность реформ, социальная и этническая напряженность, противоречия в отношения Центра с субъектами - все это результат противоречивости процесса перехода к подлинному федерализму. В условиях рынка и демократии для огромной по масштабам и разнообразной по своим климатическим, географическим, экономическим и культурным условиям страны остается только один путь - децентрализация и перераспределение полномочий в пользу регионов. Центру, чтобы добиться политической стабильности, необходимо сосредоточить в своих руках не максимальное, а оптимальное количество функций. Попытка взять побольше функций в отсутствие механизмов плановой экономики приводит лишь к потере управляемости.

В Москве политику, вырабатываемую "в пределах Садового кольца”, любят выдавать за интересы всей страны. Но природа России такова, что она состоит из народов и регионов, чьи интересы - суть государства. При этом гражданское общество следует понимать не как отказ от этнических, конфессиональных признаков, нивелирование культур и языков, а как формирование полиэтнического, поликонфессионального общества. 
В связи с этим следует сказать и о новых российских паспортах. В прессе проблему свели к графе “национальность", хотя она гораздо глубже и серьезнее. В Законе о гражданстве Российской Федерации записано право на двойное гражданство - республиканское и общеевропейское. В Договоре Республики Татарстан с Российской Федерацией о взаимном делегировании полномочий также закреплен принцип двойного гражданства, то есть татарстанского и российского. Следовательно, паспорт должен отражать политические реалии сушествования помимо русского и других государственных языков, а также необходимость закрепления республиканских гражданств. В предложенном виде паспорт для республик неприемлем. Причем позиция Татарстана не есть нечто особенное и уникальное. Посмотрите швейцарский паспорт: он заполняется на пяти языках. Даже при советском (как мы говорим, тоталитарном) режиме паспорт отражал национальную специфику.

Гражданство Татарстана - атрибут, органически присущий нашей республике. Раз Татарстан признается государством, он не может не иметь своего гражданства. При этом наше гражданство не противостоит российскому, а лишь дополняет его, учитывая те особенности, которые существуют в республике.

Россия - многонациональная страна. Этот факт крайне важно учитывать в политике. Любые попытки уйти от национального вопроса и спрятаться за обобшенными цифрами числа русских чреваты межэтническим напряжением. Народы России - коренные, то есть государствообразующие, а потому их численность не имеет особого значения. Достаточен сам факт существования народа, чтобы с ним считаться. Демократию нельзя понимать как политику навязывания воли механического большинства. Истинная демократия - та, которая умеет зашитить интересы не только большинства, но и меньшинства, адекватно отражая этническое, конфессиональное, социальное многообразие общества.

Конституция Российской Федерации, к сожалению, была подготовлена без учета интересов многих регионов, она навязывалась сверху, не учитывала уже принятые республиками конституции. При таком подходе трудно ожидать появления демократического федерализма, и не случайно более 30 субъектов отвергли конституцию во время референдума 1993 года. Поэтому сегодня выглядит по меньшей мере странным требование в одностороннем порядке привести конституции республик в соответствие с Конституцией Российской Федерации. Этот процесс может быть не только двусторонним. K сожалению, по этой проблеме не было обстоятельного разговора среди политиков и ученых. Больше слышится силовая риторика, которая мало кого пугает и совершенно не помогает делу. 
В последнее время стал острым вопрос о равноправии субъектов Федерации, причем акценты порой расставляются так, что виноватьми выглядят республики. На самом деле неравноправие регионов имеет два источника. Один - Конституция Российской Федерации, которая закрепила три типа субъектов Федерации: республики, признанные государствами со своими конституциями и внутренним гражданством; области, края и города, имеющие уставы, а не конституции; автономные округа, входяшие в состав других субъектов. Это - юридическое неравноправие, которое порождено авторами Конституции Российской Федерации. Другой источник - это естественное многообразие регионов, вытекающее из их климатических, географических, экономических, этнических и исторических особенностей. Юридические различия можно устранить, но естественные различия сохраняются. В любой федерации существуют элементы асимметрии. Этого не надо бояться, напротив, думая об учете всех существующих особенностей страны, надо понимать, что это неизбежно. Например, Калининградская область имеет свои особые проблемы, связанные с ее пограничным, анклавным положением, а следовательно, у нее иной пограничный режим и остро стоит проблема транзита, чего нет у других субъектов. Точно так же нельзя отвлечься от этнического состава республик, климатических различий, экономического потенциала различных регионов. Попытка выс́троить всех по ранжиру - рецидив советского мышления.

Актуальной проблемой российского многонационального государства выступает объективная необходимость закрепления представительства интересов этносов, особенно обладающих в силу исторически сложившихся условий весьма значительной циаспорой $в$ федеральных органах власти. На сегодняшний день эти интересы практически не представлены на общефедеральном уровне. Члены Совета Федерации выражают интересы регионов в целом, а не конкретных этнических групп. Поэтому вполне обоснованным было бы создание особого представительного органа, выражающего интересы этнических групп, либо при Президенте Российской Федерации, либо в качестве третьей палаты Федерального Собрания.

Опыт Татарстана, цругих национальных республик свидетельствует, что практика федерального строительства далеко обогнала Конституцию Российской Федерации, в которой продолжает присутствовать неоправданно жесткий подход к построению федеративных отношений. В Основном Законе России не восприняты многие сушественные для республик стороны их государственности: не нашли в нем своего отражения основополагаюшие идеи о государственном суверенитете, о договорном характере обновляющейся Федерации, закрепленные ранее в конституциях республик, отсутствует развернутая характеристика государственного статуса республик. В новом Уголовном кодексе Российской Федерации, в отли- 
чие от ранее действовавшего, республикам отказано в уголовно-правовой защите государственных символов. Федеральным законодательством в одностороннем порядке изъяты из ведения республик вопросы судебной системы и избрания судей.

В последнее время попытки нарушения суверенных прав республик в решении вопросов государственного управления становятся все более настойчивыми. Наглядный тому пример - критическая ситуация в стране после 17 августа. При полном бездействии Центра именно властные институты на местах взяли на себя всю меру ответственности (как говорится, с больной головы на здоровую).

Все это свидетельствует о том, что Татарстану вместе с другими субъектами Федерации необходимо приложить максимум усилий для изменения и дальнейшего развития конституционных основ российского федерализма, в том числе и создания целостной системы функционирования властных институтов разного уровня. Существует настоятельная потребность как повышения авторитета федеральной власти и уровня исполнения федерального законодательства в регионах России, так и усиления ответственности федеральных органов за нарушение конституционно-правового статуса субъектов Федерации. Эта работа должна вестись целенаправленно и спокойно, без давления и запугивания и, уж конечно, без угрозы санкций.

Революции взрывают нации. Для национального возрождения народов самый естественный путь - эволюционный. Согласие, как говорят мудрецы, превращает в золото глину, раздор же может превратить и золото в глину. Нации в условиях революции обречены, по общему правилу, на конфликты.

Россия, перейдя на путь федерализации, должна быть готова к тому, что этот процесс заденет все сферы без исключения: бюджет, финансы, судопроизводство, внешнеэкономическую деятельность и т.д. Республики несколько раньше осознали себя в качестве субъектов и выступают с новыми инициативами, но в затылок им дышат области и края, которые активно избирают собственные законодательные и исполнительные органы, принимают внутреннее законодательство и реально начинают управлять своей территорией. Повышение роли регионов в жизни страны неизбежно, а вместе с этим это дает надежду на то, что демократия и реформы станут необратимым процессом.

Таким образом, изложенное дает основание сделать следуюшие выводы:

1. Правовой базой российского федерализма является не только Конституция Российской Федерации, но и конституции республик, уставы субъектов, федеративные и иные договоры. Эти положения нуждаются в конституционном оформлении в главе 1 "Основы конституционного строя" Конституции Российской Федерации. 
2. Следует конституционно закрепить асимметричность Федерации.

3. Необходимо дополнить Конституцию Российской Федерации положением о том, что республики являются суверенными государствами:

- считать приоритетными направлениями развития федерализма в современных условия х обеспечение конституционно-правовыми методами реального разнообразия федеративных отношений, формируюцихся в направлении их асимметричности;

- повышать значимость договорных отношений в системе федерализма с учетом особенностей и специфики субъектов Федерации;

- считать, что позитивный результат при разрешении конфликтных ситуаций возможен только тогда, когда стороны руководствуются принципом ненасилия;

- разрешать любые спорные вопросы политического, этнического характера при полном и приоритетном соблюдении общепризнанных прав человека и гражданина;

- Федеральному Собранию Российской Федерации, законодательным (представительньм) органам власти субъектов Федерации разработать общефедеральный и региональный блоки законодательства по вопросам развития федеративных отношений, и прежде всего в сфере реализации совместных полномочий федеральных органов государственной власти и органов власти субъектов Федерации, практиковать заключение договоров;

- считать целесообразным создание в структуре Российской академии наук Института проблем федерализма;

- парламентам Российской Федерации и ее субъектов совместно с научными учреждениями, отраслевыми исполнительными ведомствами разработать концепцию становления новой отрасли права - федеративного права;

- на основе новых научно-правовых разработок субъектами законодательной инициативы рассмотреть вопрос о возможности внесения дополнений и изменений в Конституцию Российской Федерации;

- Правительству Российской Федерации совместно с палатами Федерального Собрания, с органами власти субъектов Федерации разработать механизм разграничения сферы финансирования и системы налоговых и иных поступлений в федеральный бюджет, в бюджеты субъектов Федерации и местные бюджеты с одновременным закреплением ответственности за финансирование различных видов государственных расходов.

г. Казань

Статья поступила в редакцию в ноябре 1998 года. 